\title{
Phenomenological Experiences of Women through Microcredit Programs of Upper Sindh: Stepping towards the Empowerment.
}

\author{
Sarah Wali Qazi ${ }^{1}$, M. Zaki Rashidi ${ }^{2}$
}

${ }^{1}$ Assistant Professor, Shaheed Zulfiqar Ali Bhutto Institute of Science and Technology, Karachi ${ }^{2}$ Professor, Associate Dean, and Director QLI, Iqra University

\section{A B S T R A C T}

This research study extracts the women experiences about empowerment which are comprehended through the use of microcredit. During the Literature exploration, it was obvious that there is an optimistic verdict between women empowerment and microcredit; also it alleviates the poverty of women that is a feminization of poverty. This study has assessed the lived experiences of women that how they precipitate their feelings for grasping empowerment with microcredit. This is an abductive research strategy along with the philosophy of hermeneutic phenomenology within a feminist paradigm, and generally, research design reveals the truth of numerous subjective perspectives and would help in creating the meaning of empowerment from the upper Sindh's context. This study is conducted in upper Sindh; women who availed microcredit from microfinance banks and institutions are respondents. For data collection, in-depth interviews by using interview protocol have been conducted till the saturation point. The interpretative phenomenological analysis is used to extract the themes and constructing meanings. Women associate financial ability for having three meals a day and decision taking capability as their empowerment, they think the transformation of families' lives in a better way is their empowerment. From subjective views of upper Sindh women, it was seen that microcredit transforms their lives if used in some economic activity. This study would be valuable for the policy designers of microfinance that they can plan strategies and policies accordingly.

Keywords: Women Empowerment, Microcredit, Feminization of Poverty, Hermeneutics Phenomenology

\section{INTRODUCTION}

\subsection{Background and Problem Setting}

"We know now that without gender equality and a full role for women in society, in the economy, in governance, we will not be able to achieve the world we hoped for." 
Phumzile Mlambo-Ngcuka, United Nation (UN) Under-Secretary-General and Executive Director, UN Women

This quote mirrors the small part of Sustainable Development Goal (SDG) five which is stated by UN Under-secretary- general who are concerned about the gender equality and women empowerment, these goals are designed in 2015 as portion of Agenda 2030 by United Nation (SDG 5: Achieve Gender Equality and Empower all Women and Girls, 2015)

The focus of this study is on women empowerment which is used by many development studies but the concept is not clearly explained. It's significant to understand why women are disempowered (Aithel, 1999). Disempowered is the amalgamation of 'dis' and 'empowered' that means a dearth of power or the procedure which lessens the authority of an individual or group to make decisions and mould their lives accordingly. According to researchers and experts of gender studies, the issue of disempowerment is not only associated with the developing or underdeveloped countries but women in developed countries are also suffering from this phenomena. There may be reasons associated with this like religion misinterpretation or patriarchal setup communities; lack of education, lack of financial resources or employment opportunities etc. (Bhat \& Lakshmi, 2002; Sinclair, 2012).

The main reasons are religious mis-interpreters and patriarchal culture; in fact, other many reasons instigated from these two that surged women disempowerment. Most of the religious interpreters mislead the religious opinions and suppressed, overlooked, or abused women. Every religion has some guiding principles for women as well as for men so as Islam, but interpreters, for women, construe it into the manner they want by snubbing the factual ideology behind the instructions given by religions (Chaudhry, Farhana, \& Lodhi, 2012). Women considered being inferior to men and as second-class category person (Hartmann, 2008). Due to misinterpreted instructions, women are bound at homes and restricted from getting an education, doing jobs etc. Though in the Quran and Sunnah, it is apparent that receiving an education is the responsibility of every man and woman, also woman ensures equal rights within her margins (Abukari, 2014).

In Pakistan, patriarchal community conquers where women are not only below 
the men's control but also subject to discrimination, control, dishonour, exploitations, subjugation, and violence (Moghadam, 1994). Women, even destitute of equivalent conduct in terms of basic provisions like the right to food, education, employment, healthcare, and decision making power, these sorts of variances are due to their gender differences which are a social construct (Ray, 1994). Women in the patriarchal community face more obstacles in evolving and sustaining their self-identity because men believe that only men have the right to earn and women are created for serving as housewives or sisters. Due to these facts, skilled women are excluded from economic actions; and whatsoever labour they do is neither documented nor accounted for in Gross Domestic Product (GDP) (Weiss, 2001; Ullah \& Sohail, 2013). This research study is conducted in Upper Sindh as the microfinance sector has majorly catering Punjab and Sindh, due to the qualitative study this study focused and only covered upper Sindh area.

In India, rural women are more in susceptible place and stay invisible in economics and social spheres. In the economic sphere, they feel disempowered because of the perception that they are born to stay at home and they are incapable to earn and incompetent for the market and wage economy. In a social context, women seem the second class residents. There is the misunderstanding about the rural women that they are illiterate subdued and ignorant but they are most hard working, productive adults, and young survivors of the conflicts take momentous part in the growth of the country (Ahoojapatel, 2007; Kabeer, 2005; Sahay, 1998). The woman is the worst sufferers being in the poor family because, in the male-dominant arrangement, the domestic resources slanted away from her. Women of rural areas are normally associated with the subsistence agriculture labour or with the informal segment where there is slight interference of rules and laws, minute legislative security, and lack of support from trade unions. These mechanical processes prolonged the poverty into their next generation also (Sahay, 1998; Sultana, 2011).

Under these situations, women are enforced to be in poverty which conforms the feminization of poverty. This concept was provided by Diana Pearce in 1978, which means poverty amongst the women, that is a foremost threat to the growth of the economy and its sustainability. The distressing evidence for underlying drifts of this 
phenomenon sturdily stipulates that the gender composition of poor is deviating towards women (Narasaiah, 2008).

Women's works are not acknowledged as prolific workers of the economy because they are bonded in the contractual home-based work which is not secured by the prevailing labour laws. Women usually face an absence of opportunities which lead them to work under low wages. Therefore, women indulge themselves in self-employment but having a low trade or service practices, and met with a dearth of capital and technical assistance (Warren, 1997; Sahay, 1998; Sinclair, 2012).

For being self-employed, they required financial enclosure as it is the key resource which they need for commencing and running their small enterprises. Microcredit, a product of microfinance, is notorious financial inclusions for transforming the lives of poor (Saravanan \& Dash, 2017). Microcredit is the endowment of small credits for the weak division of society explicitly for women as they are vulnerable and poorest amongst the poor (Hunt \& Kasynathan, 2002; Kwasi \& Seini, 2014). Through literature review, positive and contradictive verdicts about the tie of women empowerment and microcredit.

\subsection{Research Problem}

Women's weak position is implicit around the developing countries so in Pakistan; while we are in the 21 st century, women's role is still under the consideration. In most of the developing economies, women's roles are stimulated to be the chunk of national economic actions. Microfinance institutions are operating in a very incredible way that's top down view, bottom to up approach is lost that what women experienced with microcredit and how they realize empowerment. This study is designed to reconnoiter women's lived experiences who are using microcredit for some economic activity from Upper Sindh. Mayoux (2005) enlightened empowerment as the process which is comprehended in economic, social and political, and improved household wellbeing dimensions, this research has gauged the utmost influential sphere and how women structure meaning of empowerment. Is microcredit really supports upper Sindh women to transform their lives and mitigate their own poverty? 


\section{LITERATURE REVIEW}

Microfinance is not the new phenomenon in the emerging economies as they have fostered a long history of this concept. The rise of microfinance in Europe started in the sixteenth and seventeenth century. By then poverty lengthened oddly. Due to that reason, numerous European nations' microfinance institutions commenced developing as a banking to encourage sustainable financial situation for the poor people. Right from the opening, microfinance was deliberated as a financial intrusion and its products are ranging from micro-savings to microcredit. Besides, due to legal acknowledgment, practical rules and regulation and enforced supervision microfinance had passed through the process of mainstreaming in the twentieth century. Subsequently, the emergence of microfinance spun out to be a vital segment of formal banking (Schorghofer, 2008; Seibel, 2010).

Microfinance system worked unbelievably in the context of Ireland, in their financial market loans and credit services were very perplexing to obtain due to heavy emigration rate during the 19th century and also due to the severe macroeconomic volatility. From 1720 to 1950, their non-profit organizations offered loans to poor people without taking any sort of collateral that was the noteworthy years of microfinance (Hollis \& Sweetmanb, 2001).

According to Hartarska and Nadolnyak (2007), in Bosnia and Herzgovina microenterprise were more reliant on the internal funds that hinder in their success but because of MFIs credit and other financial products, they have relaxed access to loans. In Bosnia, microcredit is believed to be a trigger for stimulating small and medium enterprise businesses (Hartarska \& Nadolnyak, 2007).

\subsection{Microfinance and Gender Progressive Policy Development}

When in the third world, up-down developmental strategies botched to combat the burden of poverty, it ultimately gives rise to another side of the bottom to top approaches with the innumerable grass-roots tactics. Microcredit is one of the products of these grass root approaches. It delivers financial backing to poor micro-entrepreneurs who are putting efforts in the informal sector. 
According to Hernando De Soto (1989) and other economists, economy's informal sector contributes $61.2 \%$ in the economic practices, and the poor or weak segment contributes $60 \%$ in the gross domestic product (GDP) by 2000. Also, the emergent studies in countries like Indonesia, India, Bolivia, China, Cameroon, Guatemala, Kenya, Nigeria, Zimbabwe and other areas of developing world suggest the same involvement of informal sectors. The microcredit movement initiated with the identification of the importance of informal economy in the emerging countries and the key role was executed by the financial capital in nurturing the labor productivity within that sector by the poor (Woller \& Woodworth, 2001).

The development strategy based aims are based on two motives: first at the micro stage, to get rid families from the poverty and second at the macro level surges the economic output. The macro level strategies in the modern segment have been flourishing but micro level plans have confronted the ignorance because of poor family's contributions in the informal sector. The prosperous modern segment was designed on the opportunity cost of snubbed poor labor of informal market (Bateman, 2011).

The microcredit movement recommends the reverse of this strategy instead of aiming at the economic growth, contemplates the policy of poverty mitigation by augmenting the level of productivity per individual and by generating the total value of production for microenterprises operational by the poor. Accepting this policy, the other evolving goals related to factual and social benefits can also be prospered (Woller \& Woodworth, 2001; Okpara, 2010). With the increase of women proportion under the poverty line, the development policymakers had started to think on the phenomenon to bring this most ignorant part of the informal sector in the economy. It became the firm believe that sustainable growth can be achieved through the gender development associated with empowerment (Agier, 2013).

According to various studies, 60 to 70 percent of the world's poor are girls and women (Swain \& Wallentin, 2017). The fifth goal of sustainable development goals is to empower women or practice gender equality. Therefore, the development agendas are planned to promote women's economic involvements, improving their wage rates and incomes, enable them with education and health facilities, which would lower poverty 
levels, and prosperous economic efficiency. Microfinance intentions are on the same page of policies designed for gender equality and women empowerment but the plan of gender mainstreaming and equality are still ignored by most of the MFIs practitioners and policymakers (Okafor, Olagunju, \& Charles, 2010).

\section{Women Empowerment}

According to Rappaport (1987), the concept of empowerment explained as the authorized power which means an individual is allowed to act or do some particular focused things. Empowerment in a modern context defined as the power recognized and gained by the person to govern her/his own life with the help of others or by him/herself (Rappaport, 1987; Rahman, 2013). According to Friis-Hansen (2012), empowerment is the process so as an outcome which means one putting effort to achieve a relative degree of capability to effect the world (Hamill \& Stein, 2011; Friis-Hansen, 2012).

Empowerment is concerned with the development of the person and the manner they face hurdles and include themselves in the growth process for decreasing the work burden (Luttrell, Quiroz, Scrutton, \& Bird, 2009). Empowerment also seems like the availability of choices, and authority to choose among the substitutes (Mayoux, 2005). In several papers presented in the United Nations (UN), it is discovered that empowerment is imperative to understand few intervention strategies; feminist activists promote empowerment for both the women individuals and women supportive organizations. Empowerment of women needs systematic and efficient rebellion not only in some desired institutions but it is also required in the entire social patriarchal composition (Saeed, 2014; Kabeer, 2001).

\section{Feminist Theories}

Feminist theories that are connected with the second wave are explained for understanding the women empowerment concept. Three waves of feminism are discussed below;

During the first wave, feminist activities arose in 19th and 20th centuries, its emphasis is on the voting rights, in gaining the women's suffrage rights, property rights, educational rights, the improved working situations, and double sexual standard. In short, the focus is on women political rights and is on birth control (Parez, 2008). 
The second wave appeared after world war II from 1960 to 1980. The second wave is the radical wave which focused on political and cultural inequalities, which also based on the sexual liberty, integration and equal opportunities in the workplace, equal access to financial assistance, legislative influence for changing sexist laws, and merger in the political field. During this era, women were appreciated to genuinely understand the different aspects of their personal lives and reflective of a sexist construction of power. The first wave based on the absolute rights like suffrage, and on the other hand second is conscious about the equality issues like end of discrimination (Krolokke \& Sorensen, 2006).

The third one is the combination of first and second but more focuses towards the micropolitics or transversal politics that is based on the women's colors, nationality, ethnicity, religion, and culture (Rampton, 2014).

Social Feminist and Liberal theories of feminism that come under the second wave are supportive while understanding the concept of women empowerment.

Liberal Feminist Theory: It was the notion given by the liberal feminist theorist, Marry Wollstonecraft, Susan B. Anthony, Elizabeth Cady Stanton, Betty Friedan, Bella Abzug and Eisenstein, based on assumption that women must be the part of liberal framework and they must be provided with the same crucial rights to participate and share the same opportunities, to create prolific individual choices, participate in social contract and obtain the same treatment as men do. In short, liberal theory is based on the rational believes that are gender equality, individual dignity, right to pursue selffulfillment, and autonomy between men and women because they both share the same capabilities (Worell, 2002).

Socialist Feminist Theory and Marxist Feminism: Marxist believe that women are subject to subjugation and attribute the domination to the capitalist property system. The only way to defeat this oppression is to upheaval the capitalist system. According to the Jaggar (2015), social feminists considered that there is the direct relationship between the oppression of women and class structure. Societies reward men for their productive works which they are doing outside the domestic sphere but on the other hand women;'s work is hidden and excluded from the economic sphere. This phenomenon raises the 
power of men and empowers men to take control over women. Social feminists address the women situation and appeal the change of women's role in the private and public spheres. They challenge the ideologies or basis of patriarchy and capitalism. Although women are distributed on the grounds of race, ethnicity, class, and religion all of them experience the same violence and oppression because they are women. To end this oppression, it is necessary to end the gender and classes, recognition must be given to women and in all spheres of life they work side by side with the men and men see them as equal to themselves (Graf, 2012; Jaggar, 2015).

For this study, the second wave of feminism is more appropriate as empowerment and equal funding are amongst the basic pillars of that feminism movement. The term 'Second Wave' was initiated by Marsha Lear, and in America, second wave woman's rights rose out of the Civil Rights and hostile to war developments in which women, disappointed with their weak status faced legislative issues, started to gather as one to fight against biasness and for the power. In Britain, women laborers went on strike for achieving equal opportunity in the workplace. The Second wave goals are centered towards attaining freedom, the decision regarding birth control, the balance between the work and pay, equal right to avail funds and prohibition from the sexual harassment, violence at the household level, and an end to marital rape (Krolokke, 2005).

\section{Feminization of Poverty}

Diane Pearce, in between the 1950's and 1970's, during the evolution of poverty rates in the United States considered the gender patterns and elaborate the term "feminization of poverty". In 1978, she provides two ideas behind the concept of the feminization of poverty, the first is "raised number of women among the poor" and the other concept is "increased number of female headed households among the poor households".

Basically, poverty is a lack of resources, autonomies and capabilities and feminization indicates the gender biased change in the resources, freedoms or abilities.

Feminization of poverty is the phenomenon which means women experience poverty more than the men. This is common not only in developing countries but as well in the developed countries. Diana Pearce was the first one who introduced the 
terminology feminization of poverty in 1970, this concept not only refers to the financial need of the women but also considered the lack of choices, the rejection on opportunities, failure in achieving life aims, and ultimately the loss of hope (Mishra, 2018).

Diana Pearce represented the feminization of poverty as fundamental paradox.1960s and 1970s was the era when poverty considered as a female problem, even with the improvement of women's economic strength, a larger proportion of the poverty population was comprised of women. The implication of feminized poverty is not limited to the economic status of women. Feminized poverty also entailed poverty among children, which affect the wellbeing of the children. Children, growing up by experiencing poverty, deprived of healthy nutrition, health facilities, educational attainment, and low-quality cognitive development, and faced psychosocial stress. This study concluded that children who develop in poverty consider themselves poor for the lifetime and the poverty problem of women had separate dimension and need a different solution (Hulliung, 2017).

\subsection{Reflections on Women Empowerment and Micro-credit}

Kim, et al. (2007) observed that most of the lower class women are employed in very low paid jobs, so side by side small businesses enhance their incomes which improve living standards of their families and hence Self Help Group (SHG) and microfinance would reduce poverty and strengthen the women. Decision making power of women in various aspects has been advanced through microfinance and SHG. A study by Chowdhury (2008) also exhibited that those respondents who availed microfinance loans have a higher level of decision making power as compare to those who did not avail these loans, other than this, they also had the confidence to take part in economic development (Aruna \& Jyothirmayi, 2011).

In one of the study, the researcher focused on the relationship between microfinance and women entrepreneurs strength. He identified the fact that microfinance projects provide women greater economic independence and $95 \%$ of the loans are given to women. He discussed Grameen Bank model in which a group of six women is made, who must pay back their loans so that they can be entitled to successive loans (Afrin, Islam, \& Ahmed, 2008). 
Microfinance does not alleviate poverty, the author elaborates this statement that microfinance must be efficiently incorporated with better-quality adjustments so real entrepreneurs can emerge resulting in reduced household poverty especially among women entrepreneurs. In addition, microfinance should augment entrepreneurial culture among poor women like Grameen did in Bangladesh (Armendariz \& Roome, 2008; Basher, 2007)

A microfinance institution (MFIs) provide funds to women to fulfill their families' financial needs and to boost entrepreneurial spirit among women so they can take decisions and educate them, mentor them by executing strong network for women's (Strong, 2007). A Study was conducted over women empowerment in Nepal and Pakistan, which disclosed that women nurture self-assurance and can be good decision makers through MFIs activities. However, in both the countries, social and cultural perception prevents women to participate and that's why women would not contribute much and feel disempowered as they were (Gobbi, Dhakal, \& Hijazi, 2005).

A trust in Ghana researched about microfinance institution programs and women stability. The author's perspective is that the access to credit for women is their first step to empowerment journey. According to this research, women achieved a status for responsibility and trustworthiness, through different pieces of training and loans; they develop profitable relationships with the people they deal with and they feel that they have given more respect than before (Cheston \& Kuhn, 2002). It is assumed that women's empowerment has been amplified through the microfinance program which gives financial autonomy and has a positive economic impact (Swain \& Wallentin, 2007). Moreover, research studies clearly show that only microcredit facility is not enough to stabilize women although in most of the studies it is also mentioned that it is a key stick against poverty and supportive in empowering women (Arora \& Singhal, 2013). Microfinance institutions and banks consider microcredit is the crucial factor that leads to eliminating the poverty and promoting gender equality (UNDP: Women's Empowerment, n.d).

The fact "that women achieve empowerment financially and socially when financial services are provided to them" is considered a great belief across the board so 
for examining it, Steele et al. (1998) use analysis which is based on both, qualitative and quantitative, in Bangladesh to demonstrate that women participation in microfinance programs with different components is absolutely identified and contributing to their empowerment (Steele, Amin, \& Naved, 1998). Conversely, Ehlers and Main (1998) investigate microenterprise improvement programs for poor US ladies and contend that microfinance help is more negative and risky than promoters accept. Ehlers and Main (1998) build their decision with respect to the way that few females "graduate" their businesses into the formal area because of sexual orientation stipulations on the sort of organizations they decide to enter and run, and the other reason for failure is the provision of improper microfinance training regarding utilization (Ehlers \& Main, 1998).

Women faced certain major restrictions while in obtaining and utilizing microcredit which is considered as a strategy to alleviate poverty, includes less access to financial services, lack of power over microcredit etc. On the other hand, MFIs of the developing countries have the restrictions like, lack of sustainability of their own institution, shortcoming in definition, measurement, and analysis of poverty among women as in the developing countries like Pakistan the exact statistics are missing, other problem is shortcoming in measurement of women's empowerment as no quantitative or qualitative tool is specifically design for measuring the impact of microcredit on the women empowerment (Nasir, 2013).

One report highlighted numbers of areas that require attention in using microfinance as a tool for women empowerment including the influence of culture and tradition, targeted use of microfinance, the purpose of microfinance program, and support a measure to enhance microfinance (Hunt \& Kasynathan, 2002).

One study indicated four level of intervention that is required in order to improve overall effectiveness of microfinance program in women empowerment including a) The capacity and capability of microfinance institution and users including microfinance policies and procedures, b) The mission of microfinance institutions, C) The environment in which microfinance users live, work and operate, D) The belief, values, and culture of microfinance users, and staff, management, board of the microfinance institution (Underwood, 2006). 
The author recommended strings of recommendation that had been drawn from participant experience which aimed at improving microfinance as a strategy for reducing the gender dimensions of poverty and enhancing women's empowerment (Littlefield, Morduch, \& Hashemi, 2003).

\subsection{Mayoux's Three Construct Model of Empowerment with Financial Inclusion}

Women empowerment is the growth of freedom of preference and achievement to shape one's life (Nasir, 2013). The word empowerment has numerous dimensions but Mayoux (2005), has provided the three-construct model and most authors use this threedimensional model for evaluating the women empowerment. These three constructs are economic, social and political like the levels of mobilization, and the third one is improved or higher living standard. According to Mayoux (2005) and Golla, Malhotra, Nanda, \& Mehra (2011), empowerment has multiple dimensions. These are:

Women Economic Empowerment: The author recommends that women can be capable to contribute in the economy and make better decisions for their economic position. When they are able to make judgments regarding credit and savings, then they can maximize their own and family's welfare. Through one woman's wise investment, employment opportunities for other women emerged, women can access their own success, efficiently implement their business practices, can control the cash, credit instalments, savings, investments, and other assets, women can be productive as they are wise investors with intrinsic skills (Golla, Malhotra, Nanda, \& Mehra, 2011; Mayoux, 2005).

The holistic view is considered not only return in terms of money, but aspects like control over the income, knowhow of market information, access to the market, bargaining power, collective power and perception of self-financial sustainability should also be taken into account (Basargekar, 2008).

Akram and Hussain (2011) had studied 68 households which availed microcredit in the district Okara, Pakistan. They concluded that almost $86 \%$ of the respondents agreed with the developmental initiatives of microfinance that due to small loans their income level increased and their living standards had been enhanced. They agreed with 
the point that microcredit had affected their lives positively and that it was an effective strategy for poor people to escape the poverty and be economically independent (Akram \& Hussain, 2011; Ullah \& Sohail, 2013).

Higher Living Standard: Economic participation facilitates women to surge their spending on the well-being of themselves and their family. Women's economic position prevents men from the fruitless and harmful expenditure. The living standard can be improved if both men and women contribute momentous income and share responsibilities. Welfare interventions provide financial services and put emphasis on women health, security, and education which augment their abilities and skills. Higher living status reflects the improvement in the poverty level of poor households (Mayoux, 2005).

Social and Political Empowerment: Women can involve in decision making, be autonomous, self-confident and can manage their household income. Through these determinants, they can interact within the society and specified quota seats in assembly for women, empower them politically (Kiraly, 2014; Mayoux, 2008). According to the authors, if women have savings and capital with them, then they can be able to make sound decisions regarding their economic position and investment. Through wise decision making, they can generate more money and can easily uplift their own and family's wellbeing. Economic strength makes them confident and they can interact with society in a sophisticated manner (Ansari, Munir, \& Tricia, 2012; Graf, 2012) The cognitive, psychological, political and economic aspects of the empowerment are included in the elements which can strengthen women.

\section{RESEARCH METHODOLOGY}

The methodological orientation of this study is based on the hermeneutic phenomenology approach under qualitative exploratory research as this study is based on the interpretation of lived experiences. The goal of the phenomenological study is to directly explore, observe and describe the phenomena which are conscious experiences rather discussing the causal explanations of theories (Shahisaman, 2015). The abductive research strategy is used which support in interpreting experiences and used to answer 
why and what questions, but its focus is more towards the why question as it produces understanding rather than an explanation and provides reasons, not the causes. It is used to develop and construct the theories which are derived through the social actors' language, accounts, and meanings but within their context of routine activities.

The basic research philosophy through which this study can be understood is feminism. The feminist research model was applied here, which acquires a political, personal and appealing stance to the word. Its focus is on the strong commitment to change the status and conditions of women in the modern societies, to study women, and to employ female researcher, in short, the feminist research is the study on women, for the women and by the women.

\subsection{Context and Setting}

This study had been conducted in the upper districts of Sindh which comprised rural and urban areas both, natural settings were preferred as this research is based on the lived experiences in which contextual settings are significant in influencing individual life. Sindh is one of the biggest provinces where microfinance institutions are operating and have portfolios, a second reason to choose the upper Sindh is that phenomenology approach has the assumption that researcher must know the language of respondents and involved in a field. Microcredit is given in keeping the context which is weak, have skills to earn and run any economic activity and women are considered as the clients because one of the paradigms on the basis of microfinance institutions are working is women empowerment paradigm.

\subsection{Data Collection Procedure}

During the pilot interviews from the Sukker district, it was evident that the researcher's language must be Sindhi during the interview as the women in focus were not able to understand even Urdu clearly. It was crucial for exploring any phenomenon that the researcher must understand the language, culture and comfortable with the participants. The setting was natural even in the pilot interview.

In this study, only women were interviewed, who had availed loan at least once their lives and had initiated business alone or in a group or lent money to their husbands. The interviews were conducted at their homes, shops or any other places where they were 
living and running their businesses. They were selected on the basis of purposive sampling method, within the purposive sampling, maximum variation sampling was used because women who were interviewed were from different districts and regions which highlighted the heterogeneous meanings of the empowerment. This sampling was used when researcher intended to understand the phenomenon from the perspective of different people; in different times, in different settings and in different places, it maximized the diversity in the sample (Palys, 2008).

In Pakistan, there are 2.0 million active women borrowers according to the Pakistan microfinance review 2015, published in December 2016. The district-wise distribution of women borrowers was not listed but as per Pakistan Microfinance Network (PMN) report, the estimated percentage of women borrowers in Sindh was $58.4 \%$. The upper Sindh was covered in which almost half of the Sindh's districts were covered, so it is estimated that approximately $29 \%$ of borrowers were covered.

The primary data was gathered through in-depth interviews from the women who were the clients of microfinance institutes and banks. The in-depth phenomenological interviews were recorded through a semi-structured questionnaire which was interview protocol, as these were semi-structured interviews. The data was collected from the Sukker, Larkana, Shikarpur, Ghotki, Kambar Shahdadkot, Khairour, Naushehra Feroz, and Nawabshah. From every district, till saturation level interviews had been conducted. Total 39 interviews had been collected.

The interpretative phenomenological analysis is based on interpretation included the process of coding, sorting, sifting, memoing and writing. Different forms of coding like value coding, belief coding, predetermined coding etc. were also used. This process starts with the reading the verbatim individually and then by reading the whole as hermeneutic cycle refers the same that whole can be understood by reading the parts and parts can be understood by the whole.

\section{RESULTS AND DISCUSSION}

The data was analyzed through designing the different matrices and networks which reflected the degree of empowerment. Multiple categories emerged while 
analyzing the transcripts. Furthermore, the analytical memoing was done in which the experiences of participants, each district settings and observations were combined for extracting better perspective (Creswell \& Plano Clark, 2007). This study was not only based on Hermeneutics method but the analysis started with the double hermeneutics where participants made sense of their experience and interpreted it then the interpretation was done by the researcher in the second phase (Smith, Flowers, \& Larkin, 2009). The idiographic analysis was concerned with the experiences of specific participants in the particular context in which these experiences had incurred. In this study, the researcher first started with understanding the individual woman experience before moving to another woman; from every district, four to five interviews were conducted from women to extract the empowerment realization from their experiences. In the same way, the findings from the initial case were kept aside as far as possible, through practicing bracketing; the sensitivity of each and every woman's distinctive story was maintained (Smith, Flowers, \& Larkin, 2009).

Microcredit efforts like a vehicle through which importance of self-sufficiency, self-efficacy, and economic independence has reflected. The reason behind using microcredit is that poverty would be mitigated by encouraging women entrepreneurship and by women hard work. This is matched with the implications of the policy form of bootstrap theory. This theory was introduced by Dr. Stephen T. Colbert, according to him it is the fact of life that people born here to shape opportunities and lift these opportunities up with their bootstrap (Roxin, 2010). In this study, this theory is applicable in the context that when the right set of tools and social capital like education, vocational training, and financial literacy training, financial support had been provided to women then they became successful. Therefore, the findings are connected to the bootstrap theory. This disclosure divulges the significant concern that genuine women empowerment is not targeted through microcredit.

In the virtuous spiral, it had been seen that there is a difference in economic empowerment in this context; the bold characters show the differences; 


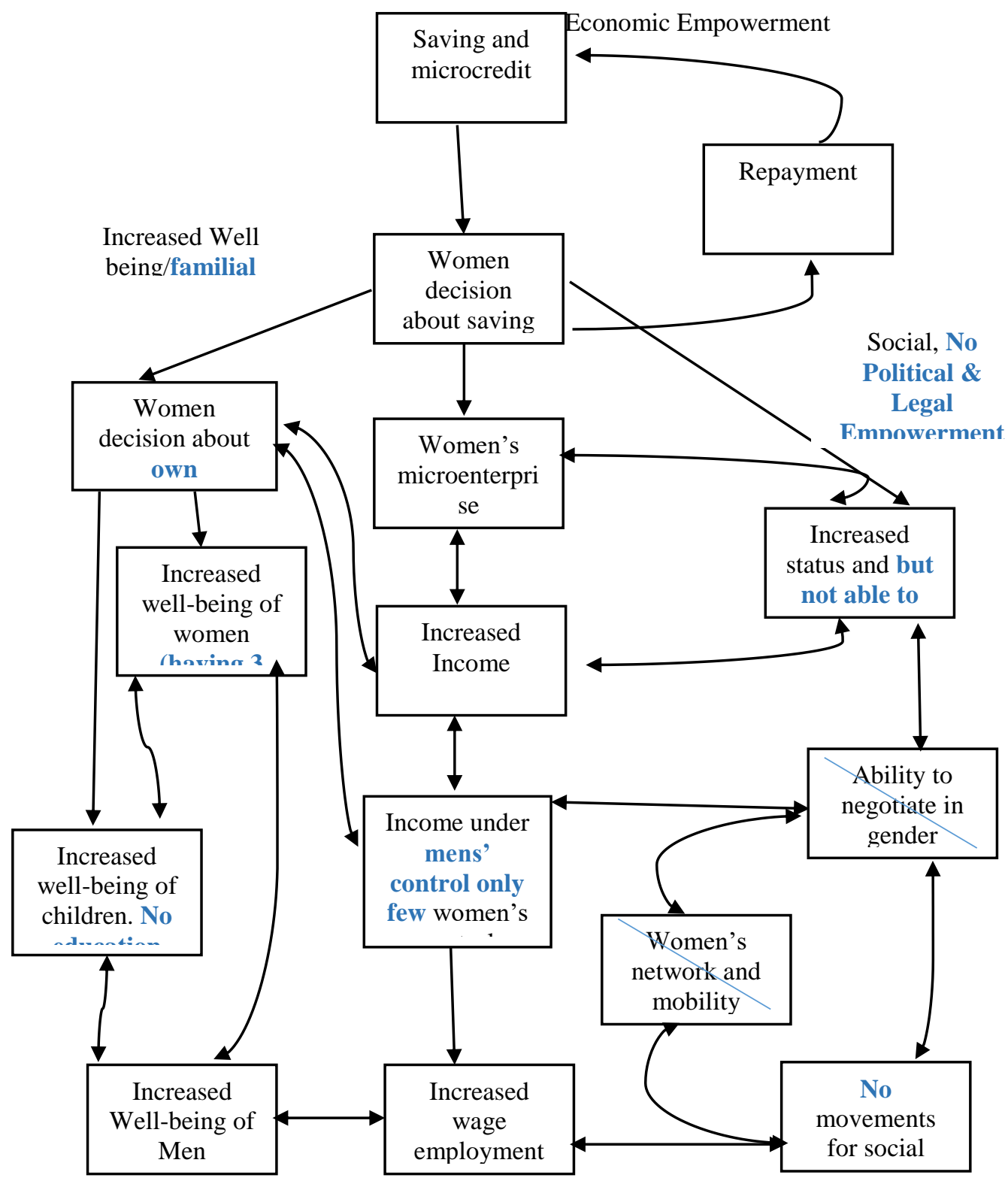

The influence of loan on the prosperity and well-being of women are expensive varying from negative to positive outcomes. The adjustments and changes in respect and prosperity are subjective and they rely upon the current conditions, similar to family life 
and gathering progressions. Hence, considering these various influences on the outcomes should be translated into a specific end goal to get a better comprehension of the changes in the wellbeing of women, and social empowerment and the context in which this tends to occur. The accepted 'righteous spirals' were challenged by the outcomes and show that the impacts resulting from microcredit cannot be rearranged and simplified. Microcredits have positively changed the way women see themselves that is self-efficacy, they have been more confident as businesspeople having a defined course in life regardless of achievements and profits. But the biggest positive result was visible on profit earning in terms of not only in their social well-being but their emotional well-being as well.

Women define empowerment as having three meals a day and their own financial stability is their strength. Familial empowerment is more influential as their consumption pattern changed towards the positivity, their children are going to school, their involvement in decision making and their male family members better lives make them happy and feeling empowered.

\section{CONCLUSION AND IMPLICATIONS}

It is gauged that financial interventions have transformed women lives towards betterment. One of the ladies was delightfully sharing that thanks to microcredit and the motivation they got through it. Now they were doing their part in the economic uplift of the family, of the society and of the country at large.

This way they are breaking the societal taboos and leading us to see a modern society of our own. It is no less than a silent revolution. The working class in Pakistan is gradually absorbing the shock inflicted to it by the existing capitalist economy as well as the feudal social system. Economic empowerment is realized with the income generation and their financial sustainability is evident from their stable earnings from the years. The economic empowerment fetches the social and mostly the familial empowerment which is based on economic activity. But this financial stability is stepping towards the mitigation of feminization of poverty.

However, due to the patriarchal mindset disempowerment of women is deeply rooted in our society and within the social values. It is not possible that the intervention 
of credit would completely alleviate poverty, fetch gender equality and women empowerment. By keeping in view the existing results, it is recommended that microfinance practitioners must design the programs as per the need of different region because every district practiced different subculture. It is also the requirement that women's perspectives should be highlighted and policies and procedures are structured as per their demand.

\section{REFERENCES}

Abukari, A. (2014). Education of Women in Islam: A Critical Islamic Interpretation of the Quran. Religious Education: The official journal of the Religious Education Association, 4-23.

Afrin, S., Islam, N., \& Ahmed, S. (2008). A Multivariate Model of Micro Credit and Rural Women, Entrepreneurship Development in Bangladesh. International Journal of Business and Management, 169-185.

Agier, I. (2013, February). Microfinance and Gender: Is There a Glass Ceiling on Loan Size? World Development, 42, 165-181. doi:https://doi.org/10.1016/j.worlddev.2012.06.016

Ahoojapatel, K. (2007). Development has a Woman's Face: Insight from within the UN. New Delhi: A.P.H Publishing Corporation.

Aithel, V. (1999). Empowerment and global action of women-Theory and practice. Dostupné na.

Akram, M., \& Hussain, I. (2011). The Role of Microfinance in uplifting Income Level: A study of District Okara - Pakistan. Interdisciplinary Journal of Contemporary Research in Business, 83-94.

Ansari, S., Munir, K., \& Tricia, G. (2012). Impact at the 'Bottom of the Pyramid': The Role of Social Capital in Capability Development and Community Empowerment. Journal of Management Studies.

Armendariz, B., \& Roome, N. (2008). Gender Empowerment in Microfinance. Munich Personal RePEc Archive.

Arora, B., \& Singhal, A. (2013, Sept-Oct). A Comprehensive Literature on Impact of Microfinance. Online International Interdisciplinary Research Journal, III(V), 346358.

Aruna, M., \& Jyothirmayi, R. (2011). The role of microfinance in women empowerment: $A$ study on the SHG bank linkage program in Hyderabad (Andhra Pradesh). Indian Journal of Commerce \& Management Studies, 77-95.

Basargekar, P. (2008). Economic Empowerment Through Microfinance. International Journal of Business Insights \& Transformation, 64-74.

Basher, M. A. (2007). Empowerment of microcredit participants and its spillover effects: evidence from the Grameen Bank of Bangladesh. The Journal of Developing Areas.

Chaudhry, I. S., Farhana, N., \& Lodhi, M. I. (2012). Women Empowerment in Pakistan with Special Reference to Islamic Viewpoint: An Empirical Study. Pakistan Journal of Social Sciences, 171-183.

Cheston, S., \& Kuhn, L. (2002). Empowering Women through Microfinance. UNIFEM.

Creswell, J. W., \& Plano Clark, V. (2007). Designing and Conducting Mixed Method 
Research. 104-106.

Crow, B. A. (n.d.). Radical Feminism: A Documentary Reader. New York: New York University Press.

Ehlers, T. B., \& Main, K. (1998). Women and the false promise of microenterprise. Gender \& Society, 424-440.

Friis-Hansen, E. (2012). The Empowerment Route to Well-being: An Analysis of Farmer Field Schools in East Africa. World Development, 414-427.

Ghodsee, K. (2004). Feminism-by-Design: Emerging Capitalisms, Cultural Feminism, and Women's Nongovernmental Organizations in Postsocialist Eastern Europe. Journal of Women in Culture and Society, 728-753.

Gobbi, M., Dhakal, N., \& Hijazi, S. (2005). Nepal and Pakistan - micro-finance and microenterprise development: their contribution to the economic empowerment of women. Geneva: International Labour Organization.

Golla, M. A., Malhotra, A., Nanda, P., \& Mehra, R. (2011). Understanding and Measuring Women's Economic Empowerment. Internation center for research, 6-9.

Graf, H. (2012). A Very Short Summary of Socialist Feminist: Theory and Practice. Feminism Socialist.

Hamill, A. C., \& Stein, C. H. (2011). Culture and Empowerment in the Deaf Community: An Analysis of Internet Weblogs. Journal of Community \& Applied Social Psychology, 388-406.

Hartarska, V., \& Nadolnyak, D. (2007). An Impact Analysis of Microfinance in Bosnia and Herzegovina. Bosnia: William Davidson Institute Working Paper.

Hartmann, H. (2008). Capitalism, Patriarchy, and Job Segregation by Sex. JSTOR, 137169.

Hollis, A., \& Sweetmanb, A. (2001). The Life-cycle of microfinance institutions: The Irish loan funds. Journal of Economic Behavior \& Organization, 291-311.

Hulliung, M. (2017). Feminization of Poverty and the Black Family: Ideological and Methodological Contestations. In The Black Family and Society, 93-108.

Hunt, J., \& Kasynathan, N. (2002). Reflections on Microfinance and Women Empowerment. Development Studies Network.

Jaggar, A. M. (2015). Just methods: An interdisciplinary feminist reader. Oxon: Routledge.

Kabeer, N. (2001). Conflicts Over Credit: Re-Evaluating the Empowerment Potential of Loans to Women in Rural Bangladesh. World Development, 63-84.

Kabeer, N. (2005). Gender equality and women's empowerment: a critical analysis of the Third Millennium Development Goal. Gender and Development, 13-24.

Kiraly, D. (2014). A social constructivist approach to translator education: Empowerment from theory to practice. Routledge.

Kirner, J. (2012, 5 23). The Three Waves of Feminism. Retrieved from the leadership of Women: http://www.leadershipforwomen.com.au/empowerment/joan-kirner-thethree-waves-of-feminism

Krolokke, C., \& Sorensen, A. (2006). Three waves of Feminism: From Suffragettes to girls. In Gender Communication Theories \& analysis: From Silence to Performance. Thousand Oaks.

Kwasi, B. R., \& Seini, W. (2014). Perceptions of Small-Scale Poultry Farmers on the Effect of Micro-Credit on Livelihood in the Atwima Nwabiagya District of Ghana. IOSR Journal of Agriculture and Veterinary Science, 7(5), 57-62.

Littlefield, E., Morduch, J., \& Hashemi, S. (2003). Is microfinance an effective strategy to reach the Millennium Development Goals? Focus note. 
Mayoux, L. (2005). Women empowerment through sustainable microfinance. Pakistan: Aga Khan Foundation Canada.

Mayoux, L. (2008). Taking Gender Seriously: Towards the Gender Justice Protocol For a Diversified, Inclusive, and Sustainable Financial Sector. Canada and Pakistan: Oxfam Novib's Women's Empowerment Mainstreaming and Networking (WOMAN) programme for Gender Justice in Economic Development.

Mishra, S. (2018). Feminization of Poverty and Dimension of Women's Agencies. Asian Journal of Multidisciplinary Studies, 6(2).

Moghadam, V. M. (1994). Gender and National Identity: Women and Politics in Muslim Societies. United Kingdom: United Nations University.

Narasaiah, M. L. (2008). Microcredit and Women. New Delhi: Discovery Publishing House Pvt. Ltd.

Nasir, S. (2013). Microfinance in India: Contemporary Issues and Challenges. MiddleEast Journal of Scientific Research, 191-199.

Offen, K. (2012). Defining Feminism: A Comparative Historical Approach. Chicago Journals.

Okafor, C., Olagunju, A. E., \& Charles, U. O. (2010). Microfinance and Gender Development Policy: Implications for Millennium Development Goals (MDGs). Nigerian Journal of Co-operative Management and Economics, 123-138.

Okpara, G. C. (2010). MICROFINANCE BANKS AND POVERTY ALLEVIATION IN NIGERIA. Journal of Sustainable Development in Africa, 12(6), 177-191.

Palys, T. (2008). Purposive sampling. In L. M. Given (Ed.). The Sage Encyclopedia of Qualitative Research Methods, 697-698.

Parez, J. (2008). THREE WAVES OF UNDERGROUND FEMINISM IN -SOFT CONSCIOUSRAISING NOVELS. Orlando: University of Central Florida.

Rahman, M. A. (2013). Women's Empowerment: Concept and Beyond. Global Journals Inc. (USA), 8-13.

Rappaport, J. (1987). Terms of Empowerment/Exemplars of Prevention: Toward a Theory for Community Psychology. American Journal of Community Psychology, 121-148.

Saeed, $R$. (2014). The role of outdoor activities in the individual empowerment of women in Pakistan: male and female perspectives. Bibsys.

Sahay, S. (1998). Women and Empowerment: Approaches and Strategies. New Delhi, India: Discovery Publishing House.

Saravanan, S., \& Dash, D. P. (2017). Microfinance and Women Empowerment-Empirical Evidence from the Indian States. MADRAS: MADRAS SCHOOL OF ECONOMICS.

SDG 5: Achieve Gender Equality and Empower all Women and Girls. (2015). Retrieved April 24, 2017, from UNWomen: http://www.unwomen.org/en/news/infocus/women-and-the-sdgs/sdg-5-gender-equality

Shahisaman, L. (2015). A PHENOMENOLOGICAL STUDY OF WOMEN IN INDIA STRIVING TO ACHIEVE WORK-LIFE BALANCE IN FINANCE WITH COMPETING PRIORITIES. United States: Proquest.

Sinclair, T. J. (2012). Beyond the Control: the Disempowerment of Women in Middle Eastern and African Literature. East Carolina University.

Smith, J., Flowers, P., \& Larkin, M. (2009). Interpretative phenomenological analysis: theory, method, and research. Sage.

Steele, F., Amin, S., \& Naved, R. T. (1998). The impact of an integrated micro-credit program on women's empowerment and fertility behavior in rural Bangladesh. 
Population Council, Policy Research Division.

Sultana, A. (2011). Patriarchy and Women's Subordination: A Theoretical Analysis. The Arts Faculty Journal.

Swain, R. B., \& Wallentin, F. Y. (2017). The Impact of Microfinance on Factors Empowering Women: Differences in Regional and Delivery Mechanisms in India's SHG Programme. (S. Garikpati, Ed.) Journal of Development Studies, 53(5), 684-699.

Ullah, M. Z., \& Sohail, D. (2013). Uncovering the Link between Micro Credit and SocioEconomic Empowerment of Women: A Case Study of Pakistan. Journal of Economics and Sustainable Development, 4(12), 9-16.

Ullah, M. Z., \& Sohail, N. (2013). Uncovering the Link between Micro Credit and SocioEconomic Empowerment of Women: A Case Study of Pakistan. Journal of Economics and Sustainable Development.

Underwood, T. (2006). Women and Microlending in Western Europe. European Microfinance Network, 145-149.

UNDP: Women's Empowerment. (n.d). Retrieved August 19, 2013, from United Nations Development Programme: http://www.undp.org/content/undp/en/home/ourwork/womenempowerment/overvi ew.html

Warren, K. J. (1997). Ecofeminism: Women, Culture, Nature. United States of America: Indiana University Press.

Weiss, A. M. (2001). Social Development, the Empowerment of Women, and the Expansion of Civil Society: Alternative Ways out of the Debt and Poverty Trap. The Pakistan Development Review, 401-432.

Woller, G. M., \& Woodworth, W. (2001). Microcredit as a Grass-Roots Policy for International Development. Policy Studies Journal, 267-282.

Worell, J. (2002). Encyclopedia of Women and Gender: Sex Similarities and Differences and the Impact of Society on Gender. Lexington: Academic Press. 